\title{
DIGITAL LITERACY OF STUDENTS AND ITS IMPROVEMENT AT THE UNIVERSITY
}

Tatiana Shopova

South-West University “Neofit Rilski” Blagoevgrad

\author{
Highlights \\ - $\quad$ The research focuses on the level of students 'digital literacy at the South-West University. \\ - The conducted analysis is supported by empirical data. \\ - $\quad$ The research shows the role of University for improving students 'digital competence.
}

\section{Abstract}

In response to the problems related to the effective use of new information and communication technologies (ICT) in education and training, this paper focuses on the key role of digital literacy and the skills of students to use new technology that will have an increasing role in the integration in the European Higher Education Area. The development of the literacy level of students and their digital competence is crucial for improving the effectiveness and efficiency of the learning process as well as for the adaptation of students to the dynamically changing labour market. This paper involves an empirical component to study and analyze the extent and manner of use of ICT by students in the learning process, to establish their motivation for improving the skills of digital literacy, in order to enable them not only to raise their academic results, but also to provide students the opportunity to be successful in society without lag behind the ever-changing demands of work and life.

\author{
Article type \\ Full research paper \\ Article history \\ Received: June 17, 2014 \\ Received in revised form: June 29, 2014 \\ Accepted: July 8, 2014 \\ Available on-line: July 31, 2014
}

\section{Keywords}

Information and communication technologies, education, digital literacy, university students, research

Shopova T. (2014) "Digital Literacy of Students and Its Improvement at the University", Journal on Efficiency and Responsibility in Education and Science, Vol. 7, No. 2, pp. 26-32, online ISSN 1803-1617, printed ISSN 1803-1617, doi: 10.7160/eriesj.2014.070201.

\section{Introduction}

The paper is an extension of the article presented on the 11 th International Conference on Efficiency and Responsibility in Education (ERIE 2014) (Shopova, 2014a).

The development of information and communication technologies (ICTs) and their integration in all spheres of people's life and work gave for the first time a possibility for a fast and unlimited access to vast information which is constantly enriched, transformed and actualized. This new model of society needs citizens who possess the necessary skills and competences to take advantage of the potential of new technologies and take active part in the economic, social and cultural life.

Eco (1996) underlines that contrary to the McLuhan (1962), according to whom with the progress of electronic media the Gutenberg era is coming to an end, the Internet does not separate us but in fact returns us back to the Gutenberg. If the TV that directs us to the form of visual images leads to a decline of literacy, the computer on the other hand implies working with verbal signs (reading words on the screen, data input, and communication in chat) restores the ability to work with printed texts. According to the Italian thinker, the computer has become an alphabetic instrument "on which one reads about the world in form of words and pages". In this way, the computer and the Internet return people back to the Gutenberg Galaxy because the consumers use written communication. Eco (1996) emphasizes an important feature of the computer communication that is related with the intellectual effort of its users who are forced to continuously improve their literacy skills and acquire the ability to work with texts. The one-dimensional text is replaced by multi-dimensional electronic hypertext that directs us to the post Gutenberg era. Eco concludes that the work in this new era requires a new form of critical competence, a new kind of educational training.

The appearance of Web 2.0 increased the scale and dynamics of data collection and management which implies the use of collective memory of the participants. It provided the users with the opportunity to take active part in the creation, sharing and combining of a variety of content (text, events, photos, videos, artwork, etc.) and knowledge to expand their cooperation in a various websites. The free choice and quick access to all kinds of services and multimedia platforms outlined new ways to finding, storing and organizing large amounts of information. This laid the beginnings of a new "hyper-connected culture" characterized with a great variety, and an access to everything in different formats, with creation of dynamic collections where information is constantly updated (Dreyfus, 2010: 33).

The Internet and new media communication technologies with their interactive and increasingly individualized digital services change people's habits and behaviour, building new value models and vital cues. They are becoming an irreplaceable source of education and self-education and important tool for the development of new literacy. "No previous technology for literacy has been adopted by so many, in so many different places, in such a short period of time, with such profound consequences. No previous technology for literacy permits the immediate dissemination of even newer technologies of literacy to every person on the Internet by connecting it to a single link on a screen" (Coiro et al., 2008: 2-3). The Web is more than a simple information search and social contact feature, 
it is also a learning tool that allows other ways to build and share knowledge (Loureiro and Bettencourt, 2014). In the digital era "the most fundamental change is not in the development of technologies as artifacts, but in their appropriation as tools and the power of these appropriations to change our thinking" (Huvila, 2012: 35).

An important priority of the Europe 2020 strategy of the European Commission (2010) is the development of new digital and media literacy skills for learning, creating, participating, and discerning use of digital media in order to meet the challenge of the global competitiveness. The educational systems were faced with the urgent necessity to provide new education programs corresponding to the needs of developing skills and abilities for effective use and understanding of digital technology as a basis for a lifelong learning.

The integration of many applications of ICTs, including different software systems and technology tools into the educational process and their successful use changes the content, methods and forms of training. The acquisition of skills and competencies in the digital age presupposes a new way of thinking and the ability of the user to continuously adapt to the new literacy required by the new technologies (Coiro et al., 2008).

Nowadays, ICTs have become a "key lever" for effective learning, and creative, innovative and responsible behavior in the new educational environment in the 21 st century. Contemporary learning theory focuses on learning as an active process of constructing knowledge, which presupposes learning to be viewed as a personal understanding and meaning making (Oliver and Herrington, 2003). It is recognized that learners need to engage in cognitively complex tasks involving such activities as problem solving, critical thinking, collaboration and self-regulation. Chai and $\operatorname{Lim}$ (2011: 4) consist that from a pedagogical perspective ICT has made the construction of "knowledge" a viable approach of developing the creative ability of students. For learners it is very important not the transmission of facts and knowledge but formulating and acquiring significant skills and abilities to research, select information sources and build their own knowledge so they can be always updated giving an adequate answer to the labour market (Goulão and Fombona, 2012: 351).

\section{Introducing the concept of digital literacy}

This part of the study draws inspiration from (Shopova, 2013) and (Shopova, 2014b).

Digital competence is determined by the European Union as one of the eight key competences for lifelong learning, which due to its versatility allows it to acquire other key skills (eg, mathematics, learning how to learn, creativity) and ensures active participation in society and economy (European Parliament and the Council, 2006: 15). This competence involves ,the confident and critical use of Information Society Technology (IST) for work, leisure and communication".

The term digital literacy was introduced in 1997 by Paul Gilster in his book Digital Literacy where the author offers its definition focussing on the ability to understand, appreciate and use the information in multiple formats that the computer can deliver. Gilster (1997) insists that one should not consider digital literacy simply as "a book about how to get around the Internet". Moreover, the ability to evaluate and interpret the information is essential. What matters is that through digital literacy one acquires basic thinking skills and core competences without which he could not orientate and perform tasks in an interactive environment.
The Gilster's concept was also used by other authors seeking to provide a more accurate understanding of digital literacy which includes a combination of different kinds of literacy based on computer/information competences focused on the skills to evaluate information and gather knowledge together with a set of understanding and attitudes (Bawden, 2008). The term digital literacy was extended and now it includes all sets of specific skills and competences needed for searching, finding, evaluating and handling information in computerized form. Bawden (2008) sees digital literacy as a "framework for integrating various other illiteracies and skill-sets, though it does not need to encompass them all".

In determining the concept of digital literacy, some authors tend to understand it as a connection with the skills and competencies needed for effective use of the Internet and digital technologies (Martin, 2005; Cartelli, 2010; Ala-Mutka, 2011, etc.). Martin (2005) consists that digital literacy involves the convergence of several types of literacy: IT literacy, information literacy, technological literacy, media literacy, and visual literacy which acquired new or increasingly important role with the advent of digital environments. Each of the authors who adhere to a similar perception has gone from focusing on specific skills to the realization that the literacy is more integrative quality linked with the deployment of skills and competencies in the context of tasks or problems of real life (Martin, 2005). Due to the development of a range needed skills, the learner can understand the scope of information channels and resources to gain confidence for the accuracy, reliability and the precision of the obtained information to have more control over their own learning.

In recent years, studies of digital literacy accentuate the need of getting beyond the basic skills of using the information and digital literacy tools and resources and developing strategies for a critical and efficient use of these means. That's why most researchers view this literacy as "continuum, with progressive stages where the basic abilities are only the first step. The upper end of the continuum contains increasing levels of cognitive competence in using the literacy in question for tasks, learning, creating and expressing new ideas, and this involves issues such as attitudes and social and cultural aspects" (Ala-Mutka, 2011: 17).

In defining the framework of digital competence (Ferrari, 2012) it came to the belief that it is not sufficient to be claimed that digital literacy includes all the skills and competencies required for Internet literacy, ICT literacy, information literacy and media literacy. There are other components that come into the picture of digital literacy and build a framework that identifies the vision of new literacy needed for living, working and citizenship in the 21 st century. Ferrari (2012) presents a comprehensive definition of digital literacy, which is built on different areas of learning - knowledge, attitudes and skills required to identify, locate, access, retrieve, store and organize the information. The focus here is primarily on solving problems, building new knowledge through technology and media in a critical, creative, flexible, ethical manner.

In their research Janssen et al (2013) expand this definition to identify twelve digital competence areas, among which may be indicated: General knowledge and functional skills; Use in everyday life; Specialized and advanced competence for work and creative expression; Technology mediated communication and collaboration; Information processing and management; Privacy and security; Legal and ethical aspects; Balanced attitude towards technology; Understanding and 
awareness of role of ICT in society; Learning about and with digital technologies; Informed decisions on appropriate digital technologies; Seamless use demonstrating self efficacy. The experts conclude that digital competence is a conglomerate of knowledge, skills, and attitudes connected to various purposes (communication, creative expression, information management, personal development, etc.), domains (daily life, work, privacy $\&$ security, legal aspects), and levels (Janssen et al, 2013: 480).

The present study, we will be based on this broader definition of digital literacy and will direct attention to the role of digital literacy skills of students to use new technologies, which will have increasing importance in the development of university education. The paper presents the empirical results of a survey performed in September 2013 at the SWU among first- and second- year students in humanities. The aim of the survey is to understand: a) How university students use information technology in the course of their training, b) What is the level of digital literacy of students in humanities, c) What is the motivation of students to enhance their digital literacy skills and competences, d) What are the ways and means of improving the level of digital literacy of university students (especially from first and second courses). It was important to establish the attitude of students towards the use of digital technologies for effective searching, finding, critical evaluation and presentation of information obtained from various sources for educational purposes. We want to show the role of South-West University in Bulgaria in the process of encouraging and developing the information-communication skills of students as a response to the European priorities in the area of digital technologies and future education.

\section{Materials and Methods}

This part of the study draws significant inspiration from (Shopova, 2014).

The task that is placed in front of today's students is related with mastering the concepts, theories and basic knowledge of different disciplines and with understanding of all the necessary criteria and strategies to find relevant information that is valid for their area of study or research (Area, 2010). For university students it is necessary to have knowledge and skills in the field of digital technology to be able to use information effectively in its different forms (e-publications, online video, audio recordings, digital libraries, databases, etc.). Furthermore, students need to be able to work critically with the information resources that they find for the purposes of their learning activity and have the competencies to handle independently in resolving scientific issues in projects, studies, etc.

Therefore, a team from the Center for New Media and Digital Culture at SWU "N. Rilski" conducted a survey among 60 firstand second-year students who were divided unevenly as far as gender is conserned : 20 men and 40 women took part from the Department of Cultural Studies at the Faculty of Arts and the Department of Philosophy and Political Science at the Faculty of Philosophy of the University. The team members has suggested that first-and second-year students have serious problems in the learning process and need more support from lecturers and librarians to effectively use the Internet and information technologies as well as to seamlessly overcome the difficulties encountered by students in finding and using information needed to be successful in their course works.

The study was conducted through the method of direct personal inquiry through pre-designed questionnaire. It was based on the developed by the Association of University and Scientific
Libraries standards and guidelines to improve information and digital competences in higher education (American Library Association, 2000), but also on the proposed by the Stanford University modules for assessing of information literacy among students. The questionnaire consisted of five set of questions.

The first set of questions was related to the computer literacy of students and their ability to: Work with computers to access to information; Use computer tools for word processing; Create and form documents; generate tables, pictures and images; Use Microsoft Excel, databases, etc; Create graphs and charts, create presentations and slideshows, etc.

The second set of questions was to understand the students' access to the Internet and the skills to use the Web and to participate in the Internet environment. Students had to answer the following questions: What is their daily access to the Internet? How they use different tools and online resources to search for, find and retrieve information? Do they understand the basic concepts of the Internet including security issues? Do they use search tools for finding and retrieving information? Do they use e-mail and work with attachments?

The third set of questions was related to establishing the ability of students to search independently and find effectively the relevant information and information resources for specific tasks; knowing and using library information resources in the network; using appropriate search strategies in different information systems (e.g. Google TM, Yahoo TM, Yandex and other resources for finding information), etc.

The fourth set of questions concerned the students' skills for critical and reflexive attitude towards information and responsible use of information technology as a prerequisite for social adaptation and work in the digital society. It presented such students' competences as: evaluating, analyzing, synthesizing, using and interpreting information, deriving new knowledge from acquired information and understanding the economic, legal and social issues related to the ethical and legal use of information.

The fifth set of questions aimed to show the motivation of students to improve their skills and competencies for using the Internet and digital technologies. Therefore, respondents were asked to answer the following questions: Do you think that your digital skills in the learning process are enough? Would you like to participate in training courses to increase your digital literacy? In what forms of training you prefer to be included in order to acquire skills for using ICT?

\section{Results and Discussion}

This part of the study draws significant inspiration from (Shopova, 2014).

1. The study showed that the majority of respondents positively evaluated their ability to work with computers to access information, as $76 \%$ of them indicated that these skills were good, $14 \%$ - very good and $10 \%$ - excellent. They used computer tools for word processing ( $40 \%$ said that their skills were good, $46 \%$ - very good and $14 \%$ - excellent). They were able to create and format documents, to generate tables, pictures and images (76\% assessed these skills as good, 14\% - very good and 4\% excellent). As for the ability to create presentations and present a slide show, $70 \%$ of students admitted they can make this well, $12 \%$ - very well and 18\% - excellent (Table 1). 
Shopova T. - ERIES Journal vol. 7 no. 2

\begin{tabular}{|l|c|c|c|}
\hline $\begin{array}{l}\text { Ability of students to work } \\
\text { with computer / ICT }\end{array}$ & Excellent & $\begin{array}{c}\text { Very } \\
\text { Good }\end{array}$ & Good \\
\hline $\begin{array}{l}\text { Using the operating system to access } \\
\text { the information }\end{array}$ & $96 \%$ & $3 \%$ & $1 \%$ \\
\hline $\begin{array}{l}\text { Working with computers to access the } \\
\text { information }\end{array}$ & $10 \%$ & $14 \%$ & $76 \%$ \\
\hline Word processing & $14 \%$ & $46 \%$ & $40 \%$ \\
\hline $\begin{array}{l}\text { Using the Microsoft Excel,databases, } \\
\text { etc. }\end{array}$ & $12 \%$ & $30 \%$ & $58 \%$ \\
\hline $\begin{array}{l}\text { Creating and formatting documents, } \\
\text { tables, pictures and images }\end{array}$ & $4 \%$ & $14 \%$ & $76 \%$ \\
\hline $\begin{array}{l}\text { Creating presentations and slideshow } \\
\text { presentation }\end{array}$ & $18 \%$ & $12 \%$ & $70 \%$ \\
\hline
\end{tabular}

Table 1: Computer/ICT skills of students

2. The survey data indicated that the majority of students used the Web and had daily access to the Internet (96\%), 72\% of which - mainly at home and $24 \%$ - at the university. They successfully used the Internet and information technology in the learning process having in mind that the easy and fast access to the needed information was facilitated them in their learning activities allowing them to respond to a considerable degree to the requirements for active participation and improve their academic results. Most of respondents indicated they used without difficulty some search tools to find and retrieve information (98\%). They were able to: identify search results (78), know how to use e-mail (98\%), create and send emails, and work with attachments (91\%). Those who understood the basic Internet concepts, including security issues, however, were only $2 \%$, and a significant portion answered "partially" $(66 \%)$ or "no" (32\%). Those students who could create their own web pages were only $7 \%$ (Table 2 ).

\begin{tabular}{|l|c|c|c|}
\cline { 2 - 4 } \multicolumn{1}{c|}{} & $\begin{array}{c}\text { Every } \\
\text { day }\end{array}$ & $\begin{array}{c}\text { At } \\
\text { home }\end{array}$ & $\begin{array}{c}\text { At the } \\
\text { university }\end{array}$ \\
\hline Internet Access & $96 \%$ & $72 \%$ & $24 \%$ \\
\hline Basic Internet Skills & Yes & Partly & No \\
\hline Using the WWW & $96 \%$ & $4 \%$ & - \\
\hline $\begin{array}{l}\text { Using search tools to find and } \\
\text { retrieve information }\end{array}$ & $98 \%$ & $2 \%$ & - \\
\hline Identifying the search results & $78 \%$ & $15 \%$ & $2 \%$ \\
\hline Using E-mail & $98 \%$ & $2 \%$ & - \\
\hline $\begin{array}{l}\text { Creating and sending emails, and } \\
\text { working with attachments }\end{array}$ & $91 \%$ & $9 \%$ & - \\
\hline $\begin{array}{l}\text { Understanding the basic Internet } \\
\text { concepts }\end{array}$ & $2 \%$ & $66 \%$ & $32 \%$ \\
\hline $\begin{array}{l}\text { Creating own web pages with text, } \\
\text { images, and hyperlinks }\end{array}$ & - & $7 \%$ & $93 \%$ \\
\hline
\end{tabular}

Table 2: Internet access and basic students`internet skills

3. As for information literacy of students, data showed that $44 \%$ of respondents did not have effective and efficient access to information, and were satisfied with the information retrieval. More than half of the respondents recognized that they were partially satisfied by the searching for information. Half of the students said they could identify the key concepts and terms that describe the information need. $68 \%$ did not have difficulties when they have to determine different types and formats of potential sources of information (e.g. multimedia, databases, audio /video, book). Moreover, the majority of them (90\%) did not have skills to distinguish the most important characteristics of the separate library information resources on the Web. $88 \%$ of respondents could not identify types of resources in the catalogue of the electronic university library to retrieve information (Table $3)$.

\begin{tabular}{|l|c|c|c|}
\hline $\begin{array}{l}\text { Abilities for seeking and retrieving } \\
\text { information }\end{array}$ & Yes & Partly & No \\
\hline Effective and efficient access to information & $44 \%$ & $56 \%$ & - \\
\hline Satisfaction with information search & $44 \%$ & $56 \%$ & - \\
\hline $\begin{array}{l}\text { Identification of key concepts and terms } \\
\text { that describe the information need }\end{array}$ & $50 \%$ & $50 \%$ & - \\
\hline $\begin{array}{l}\text { Determination of different types } \\
\text { and formats of potential sources of } \\
\text { information (eg, multimedia, databases, } \\
\text { audio / video, book) }\end{array}$ & $68 \%$ & $32 \%$ & - \\
\hline $\begin{array}{l}\text { Construction of strategies for locating } \\
\text { information }\end{array}$ & $48 \%$ & $52 \%$ & - \\
\hline $\begin{array}{l}\text { Differentiation of the major characteristics } \\
\text { of separate library information resources } \\
\text { on the web }\end{array}$ & - & $10 \%$ & $90 \%$ \\
\hline $\begin{array}{l}\text { Identifying types of resources in the } \\
\text { catalogue of the electronic university } \\
\text { library }\end{array}$ & $2 \%$ & $10 \%$ & $88 \%$ \\
\hline & Google & Yahoo & Others \\
\hline Using Search Engines to find information & $83 \%$ & $7 \%$ & $10 \%$ \\
\hline
\end{tabular}

\section{Table 3: Students`ability for seeking and retrieving information}

The survey indicated that students who could construct appropriate strategies for locating information in diverse information systems using different interfaces and search engines were $48 \% .83 \%$ of respondents preferred Google over other search engines for finding information. Most students (82\%) recognized they rarely used print media (books, newspapers, magazines, etc.) to assist the learning activities and relied heavily on the electronic media (44\%). Few were those who regularly used online video $(15 \%)$, online photo galleries $(10 \%)$, electronic audio records (12\%), virtual museums $(8 \%)$ and digital libraries (5\%) (Table 4).

\begin{tabular}{|l|c|c|c|}
\hline $\begin{array}{l}\text { What resources do you prefer to } \\
\text { use? }\end{array}$ & Regularly & Sometimes & Rarely \\
\hline $\begin{array}{l}\text { Print media - newspapers, } \\
\text { magazines, books, } \\
\text { encyclopaedias, etc. }\end{array}$ & $6 \%$ & $12 \%$ & $82 \%$ \\
\hline $\begin{array}{l}\text { E-media - newspapers, } \\
\text { magazines, books, } \\
\text { encyclopaedias, etc. }\end{array}$ & $44 \%$ & $23 \%$ & $33 \%$ \\
\hline Online video & $15 \%$ & $20 \%$ & $65 \%$ \\
\hline Electronic audio records & $12 \%$ & $10 \%$ & $78 \%$ \\
\hline Online photo galleries & $10 \%$ & $7 \%$ & $83 \%$ \\
\hline Virtual museums & $8 \%$ & $5 \%$ & $87 \%$ \\
\hline Digital libraries & $5 \%$ & $5 \%$ & $90 \%$ \\
\hline
\end{tabular}

\section{Table 4: Use of information resources by students}

4. The next set of questions was related to the skills of students for critical and reflexive attitude towards information and responsible use of new technology. The study revealed that most students were able to analyze and synthesize information (71\%), compare information obtained from different sources (73\%), and know how to interpret and present information (52\%). Fewer were those who had no skills to critically evaluate information and sources $(45 \%)$ and had difficulties when they have to critically evaluate print and online resources based on specific criteria $(72 \%)$, verify the authenticity and reliability of the data collected (64\%). Although the majority of respondents $(75 \%)$ said they were aware of copyright, many of them $(25 \%)$ only occasionally followed laws, regulations and tags associated with the access to and use of the information resources, while $38 \%$ did not do this. (Table 5) 


\begin{tabular}{|l|c|c|c|}
\hline Skills for effective use of information & Yes & Partly & No \\
\hline Analyzing and synthesizing information & $71 \%$ & $18 \%$ & $11 \%$ \\
\hline $\begin{array}{l}\text { Comparing the information obtained from } \\
\text { different sources }\end{array}$ & $73 \%$ & $20 \%$ & $7 \%$ \\
\hline Interpretation and presentation of information & $52 \%$ & $35 \%$ & $13 \%$ \\
\hline Critical evaluation of information and sources & $45 \%$ & $38 \%$ & $17 \%$ \\
\hline $\begin{array}{l}\text { Critical evaluation of print and online } \\
\text { resources based on specific criteria }\end{array}$ & $28 \%$ & $52 \%$ & $20 \%$ \\
\hline $\begin{array}{l}\text { Verification of the authenticity and reliability } \\
\text { of the data collected }\end{array}$ & $46 \%$ & $54 \%$ & $10 \%$ \\
\hline $\begin{array}{l}\text { Understanding of what is the copyright and } \\
\text { its ethically use }\end{array}$ & $75 \%$ & $16 \%$ & $9 \%$ \\
\hline $\begin{array}{l}\text { Following laws, regulations, etiquette related } \\
\text { to the access and use of the information } \\
\text { resources }\end{array}$ & $25 \%$ & $35 \%$ & $40 \%$ \\
\hline
\end{tabular}

Table 5: Students`skills for effective use of information

5. The last group of questions aimed to provide the motivation of students to develop their skills and competencies for using the Internet and digital technologies. The study found that $56 \%$ of the respondents were willing to participate in specific training courses that would give them greater opportunities to increase their digital competence. To the question what types of training they prefer, $68 \%$ of respondents answered that these were courses included in the curriculum of the specialty, while $12 \%$ of them said they could participate in specialized courses outside the specialty curriculum (in paid form of learning). There were also students (44\%) who did not wish to participate in any training courses, lectures, seminars, etc. (Table 6)

\begin{tabular}{|l|c|c|}
\hline Motivation of students & Yes & No \\
\hline Would you like to participate in training courses? & $56 \%$ & $44 \%$ \\
\hline $\begin{array}{l}\text { Would you like to be involved in courses included } \\
\text { in the curriculum of the specialty? }\end{array}$ & $68 \%$ & $32 \%$ \\
\hline $\begin{array}{l}\text { Would you like to be involved in specialized courses } \\
\text { outside the specialty curriculum? }\end{array}$ & $12 \%$ & $88 \%$ \\
\hline
\end{tabular}

Table 6: Motivation of students to improve their digital competence

To sum up, we can say that the average score, which put $66 \%$ of the respondents on their computer literacy is "good" and only $17 \%$ of them indicate "very good". $42 \%$ say they have difficulties using the Internet for various activities, including helping their learning process. Students recognize that the information they obtain is insufficient to enable them to be valued more highly by lecturers. Average $56 \%$ of the respondents mark they experience difficulties when they have to search for and find information effectively and use specific information resources as the most preferred are e-publications (44\%).

The study finds that the majority of students have no skills needed to take advantage of the electronic library at the university and do not know how to use its rich information recourses. Average $48 \%$ of the respondents recognize they have difficulty with critical and creative attitude towards information and its usage in an ethical and responsible manner. Many students do not know how to interpret the reference to a paper or journal, how to search databases effectively, or to assess the quality of different websites. Students typically rely heavily on one search engine to find information on the Web. Along with this, many of them copy information directly from websites without citing and have no awareness on the ethical issues related to the copying and citing when they use various sources to prepare their essays or course works. Irrespective of insufficient proficiency in the skills many students are not motivated to participate more actively in organized courses at the University.

The researchers note that the access to computers and the Internet, the ability to use word processing tools, create and send emails, work with attachments, use operating system to access information, is no guarantee of the competence of students and so are to be made more efforts to achieve higher levels of learning, connected with acquisition of competences to effectively solve problems and tasks. Students need to learn how to utilize those incredibly diverse and powerful technologies efficiently and effectively to search for, retrieve, organize, analyze, evaluate information and then to use it for specific decision-making and problem-solving ends (Horton, 2008: 5-6). In order to enable students to adapt to the challenges of the digital society and new practices for electronic learning environment, it is required to identify effective ways to invite, encourage and motivate towards the utilization of high quality theoretical and applied knowledge and skills for working. It is especially important to intensify the research activities of students by involving them in problem research groups and research projects. In this regard, Wolf (2007:10) underlines: "Open-ended tasks that are project -and research-based and require interpretation increase opportunities for students to increase motivation and engagement in specific subject areas".

Mastering digital information, the ability to find, understand, evaluate and use information effectively and ethically in order to meet their personal and academic needs is fundamental to the learning process of students. Pérez and Torelló (2012: 1116) consist that ICTs have to be understood "as symbolic and cultural technological systems needed to create, manage, analyze, communicate and transform information into new relevant knowledge". According to the authors this opens an opportunity for the person-the professional to be the one who properly uses and integrates ICTs, not only into its teaching functions, but into the rest of its professional roles, according to the best of its knowledge and professional experience.

The survey indicates some learning gaps to effectively use the Internet and ICTs by first- and second-year students in humanities. This suggests that it's necessary for lecturers to increase efforts to raise awareness of the nature and importance of digital literacy in education. The study highlights an understanding among researchers that digital literacy must be considered as a situated practice, and that it concerns functional and communicative competencies rather than acquiring a set of technical skills (Knutsson, Blåsjö and Hållsten, 2012). It is outlined the significance of acquiring key skills for seeking, finding and managing information, for critical and efficient use of digital tools and information recourses, and creation of new knowledge. For experts and scholars the old pedagogy delivered with new technology does not work. The advancement in information and communication technology has a significant impact on the way teachers teach and the way students learn, and for technology to result in quality learning (Pérez and Torelló, 2012).

It is highlighted the importance of acquisition of competences in relation to communication in the virtual space, as well as the ethical and social challenges that arise in this context, the skills needed to search for information and management, to participate in different networks, etc. (Henriksen, 2011). So Henriksen (2011) suggests considering the issue of effective use of the opportunities for technology-mediated learning, on the one hand, and the processes of digitally based learning within and outside educational institutions, on the other. 
The survey results show on which specific skills the university and lecturers should pay more attention to ensure a more effective inclusion of students in education which is important for the adaptation of students to the challenges of the digital society and new learning practices. The efforts of the university suggest also more active involvement of students in various courses, and mastering skills for a more effective approach to finding and using information that suggests its critical analysis and evaluation, creative use of different sources to solve problems and manage information in a responsible manner. From this perspective, especially suitable are the courses included in the curriculum that will provide the skills needed for using digital technologies. For example, we can offer such courses as "Basic Computer/ICT Skills", "Digital Literacy Skills", "Academic Writing", etc. whose purpose will be to improve the students' knowledge and skills, meaningful and practical adequate the requirements of modern education. The realized courseware will allow more active work in the direction of integration of digital literacy in the learning environment focusing on certain important aspects of development of students' digital competences. The role of library professionals who can offer information literacy services through self-directed learning and "cooperation with lecturers, so that the latter can incorporate content into their teaching-learning activities that contributes to students' information competency" (Gomez Hernandez, 2010: 45 ) it's important. Library staff must endeavor to offer programs for digital literacy, including skills training for use of the library and its information educational resources. Denchev and Pavlova (2009: 57) indicate the primary objectives of the e- library "to support learning in the processing of digitized information, encourage and motivate its use, to convince students of the benefits of digital resources without ignoring the traditional media (learning relies on various electronic databases format containing the most diverse information)". Involving students in additional short-term or long-term courses (with paid form of learning) may also contribute to the acquisition of important knowledge and skills for that are not given enough places in the curricula.

Undoubtedly, the efforts to increase digital literacy of university students should begin in primary and secondary school to provide basic computer and information literacy competences or "cognitive and operational skills and attitudes necessary for the effective use of information and communication technologies" (Rambousek, V. et al., 2013: 246). The conduct of seminars and lecture ability to access online tutorials, e-books and other forms of enhancing students' digital literacy, through which we can expect the development of a wide range of skills for searching, identification, critical evaluation and use of information for a more independent and creative behavior in the digital environment should not be underestimated.

\section{Conclusion}

In the European Union initiative called "e-Learning" (2000) clearly was identified the need to increase the key competences and later in the adopted Communication on "e-Skills for the 21 st Century", EU indicated the importance to consider the problem of digital (not) literacy (Commission of the European Communities, 2007). In the new educational environment with integration of ICT into subject teaching the students ' learning gets a new dimension. For more flexible adaptation to a lifelong learning, the role of digital competence is increasing. Its construction requires confident and critical use of information technology for learning, working and communicating. Students need to "learning to learn", which involves increased control over the process of one's own thinking and education which means an "ability to pursue and persist in learning, to organize one's own learning, including through effective management of time and information, both individually and in groups" (European Parliament and the Council, 2006). By acquiring fundamental skills as literacy and competences in the area of digital technologies, one should be able to easily access information, acquire, analyze and integrate new knowledge and skills, as well as have "the ability to persevere with learning, to concentrate for extended periods and to reflect critically on the purposes and aims of learning".

Our study shows that improving digital literacy of students and their skills in using ICTs is an important condition for the successful performance and achieving better results in the learning process. Acquiring required digital literacy competencies is a prerequisite for expanding access to information and communication technologies in order to ensure greater competitiveness of young people on the labor market.

The majority of young people, who come to the university, do not have the skills needed for using the Internet and information technology, when they have to solve scientific problems, to perform different tasks individually or in a teams. They are good at using social networking, e-mails or skype, surfing the internet, showing as active gamers and participants in virtual communities, but their knowledge and competences for effective use of new technology in the learning process are often superficial. And here it's important the role of the SouthWest University to adopt a comprehensive strategy, which can speed up the process of motivating and supporting students in the direction of development, improvement and enhancement of their skills through effective use of the vast potential of digital technologies. The achievement of greater efficiency of the learning process in the university environment requires the acquisition of skills to search for and find useful information and resources, but also the ability to analyze and synthesize received information, share and discuss different ideas and perspectives that can support students to solve problems in teams.

The study team considers that the data obtained from the research can be used: 1 . As a basis for further research on digital literacy among students of the South-West University; 2. As the basis of research of digital competence of students in Bulgaria; 3. For comparison with data from future research in this area in the university; 4 . In the processes of identifying needs and interests of Bulgarian university students to improve their digital literacy; 5 . In the process of motivating students to develop their digital literacy skills and competences for working and creative expression in the new learning environment.

\section{References}

Ala-Mutka, K. (2011) Mapping Digital Competence: Towards a Conceptual Understanding, Seville: JRC - IPTS.

American Library Association [ALA] (2000) Information Literacy Competency Standards for Higher Education. Retrieved from http://www.ala.org /acrl/ sites/

Area, M.(2010) 'Why Offer Information and Digital Competency Training in Higher Education?' In: Information and Digital Competencies in Higher Education" [online monograph]. Revista de Universidad y Sociedad del Conocimiento (RUSC). Vol. 7, No 2. UOC. 
Bawden, D. (2008) Digital Literacy. SciTopics. December 29. Retrieved from http://www.scitopics.com/Digital_Literacy.html

Chai, C. and Lim, C. (2011) 'The Internet and teacher education: Traversing between the digitized world and schools', Internet and Higher Education 14, pp. 3-9.

Cartelli, A. (2010) 'Frameworks for Digital Competence Assessment: Proposals, Instruments, and Evaluation', Proceedings of Informing Science \& IT Education Conference (InSITE), pp. 561-573.

Coiro, J., Knobel, M., Lankshear, C., \& Leu, D. J. (2008) 'Central Issues in New Literacies and New Literacies Research', Handbook of Research on New Literacies. New York: Lawrence Erlbaum Associates, pp. 1-22.

Commission of the European Communities (2007) E-skills for the 21st century: fostering competitiveness, growth and jobs. European Commission, Brussels, 7.9.

Denchev, S. and Pavlova, I. (2009) 'Role of digital libraries in the university information environment', Annual of "Informatics" Section, Union of Scientists in Bulgaria, Volume 2, pp. 56-60.

Dreyfus, H. (2010) On the Internet. Sofia: Critique\&Humanism Publishing House

Eco, U. (1996) From Internet to Gutenberg, November 12. Retrieved from http://www.umbertoeco.com/en/from-internetto-gutenberg-1996.html

European Commission (2010) A Digital Agenda for Europe (DAE). Brussels, 19.05.2010, COM(2010) 245, Retrieved from http://eur-lex.europa.eu /LexUriServ/Lex Uri erv. Do ? uri = COM:2010:0245:FIN:EN:HTML

European Parliament and the Council (2006) 'Recommendation of the European Parliament and of the Council of 18 December 2006 on key competences for lifelong learning'. Official Journal of the European Union, L394/310.

Ferrari, A. (2012) Digital Competence in Practice: An Analysis of Frameworks, European Commission-JRC-IPTS, Luxembourg Publications Office of the European Union.

Gilster, P. (1997) Digital Literacy, New York: John Wiley \& Sons.

Gomez Hernandez, J. A. (2010) 'University Libraries and the Development of Lecturers' and Students' Information Competencies', In: Information and Digital Competencies in Higher Education" [online monograph]. Revista de Universidad y Sociedad del Conocimiento (RUSC). Vol. 7, No 2. UOC.

Goulao, M. and Fombona, J. (2012) 'Digital Literacy and adults learners' perception: The case of a second chance to University', Procedia - Social and Behavioral Sciences 46, pp. 350 - 355.

Henriksen, C. (2011) Media and ICT in a Learning Perspective, Accessed 24 November. Retrieved from http://www.dpu.dk/en/ research/researchprogrammes/mediaandict/

Horton, F. W. Jr (2008) Understanding Information Literacy: A Primer, Paris: UNESCO.

Huvila, I. (2012) Information Services and Digital Literacy: In search of the boundaries of knowing (Chandos Information Professional Series). Oxford.

Janssen, J., Stoyanov, S., Ferrari, A., Punie, Y., Pannekeet, K., Sloep, P. (2013) 'Experts' views on digital competence: commonalities and differences', Computers \& Education, Volume 68, October, pp. 473-481.

Knutsson, O., Blåsjö, M. and Hållsten, S. (2012) 'Identifying different registers of digital literacy in virtual learning environments', The Internet and Higher Education, vol 15,
October, 4, pp. 237-246.

Loureiro, A. and Bettencourt, T. (2014) 'The use of virtual environments as an extended classroom - a case study with adult learners in tertiary education', Procedia Technology 13, pp. 97-106.

Martin, A. (2005) 'DigEuLit - a European framework for digital literacy: A progress report.' JeLit, Journal of eLiteracy, 2(2).

McLuhan, M. (1962) The Gutenberg Galaxy: The Making of Typographic Man, University of Toronto Press.

Oliver, R. and Herrington, J. (2003) 'Exploring technologymediated learning from a pedagogical perspective', Journal of Interactive Learning Environments, 11 (2), pp.111-126.

Perez, K. and Torelló, P. (2012) 'The digital competence as a cross-cutting axis of higher education teachers' pedagogical competences in the european higher education area', Procedia Social and Behavioral Sciences 46, pp. 1112 - 1116

Rambousek, V., Štípek, J. and Procházka J. (2013) 'Primary Findings of the Research on ICT Literacy Education Pupils' and Teachers' Competencies in Primary and Lower Secondary Schools', Journal on Efficiency and Responsibility in Education and Science, Vol. 6, No. 4, pp. 245-264.

Shopova, T. (2013) 'Information and Digital Literacy - for a more quality university education', Scientific Bulletin Education Sciences Series, no.2, pp. 130-151.

Shopova, T. (2014a) 'Integration of ICTs in Education and Raising the Digital Literacy of Students in the University Environment', In: Proceedings of 11th Conference on Efficiency and Responsibility in Education (ERIE 2014), Prague: CULS, pp. 703-711.

Shopova, T. (2014b) 'Razvitie na digitalnata kompetentnost u studentite', Nota bene, br. 26.

Wolf, S. (2007) 'Information Literacy and Self-regulation: A Convergence of Disciplines', School Library Media Research, Volume 10. 